\title{
Toxic compounds in homemade spirits in Bosnia and Herzegovina: A pilot study
}

\author{
Marjanovic, A. ${ }^{\text {, }}$ Omeragic, E. a , Djedjibegovic, J. ${ }^{\text {a }}$, Turalic, A..$^{\text {, Lugusic, A. }}$, Caklovica, F. , \\ Sober, M. ${ }^{a}$ \\ ${ }^{a}$ Faculty of Pharmacy, University of Sarajevo, Zmaja od Bosne 8, 71000 Sarajevo, Bosnia and Herzegovina \\ ${ }^{b}$ Faculty of Veterinary Medicine, University of Sarajevo, Zmaja od Bosne 90, 71000 Sarajevo, Bosnia and Herzegovina
}

Article info

Received: 06/05/2019

Accepted: 07/10/2019

Keywords:

homemade spirits

hydrocyanic acid methanol

*Corresponding author:

Aleksandra Marjanović

E-mail: aca1902@gmail.com

Phone: 00 387-61-709-562

\begin{abstract}
The main aim of this preliminary study was to investigate the presence of potentially toxic compounds (methanol, hydrocyanic acid and urea) in homemade fruit spirits produced in different parts of Bosnia and Herzegovina. A total of 15 samples of 8 different fruit spirits were analyzed (apple, apricot, cherry, grape, pear, plum, quince and juniper). Content of hydrocyanic acid was higher than maximum permissible level in 5 out of 15 samples. In general, the average content of methanol was higher in samples from Bosnia comparing to the samples from Herzegovina (874.62 vs. $563.99 \mathrm{~g} / \mathrm{hL}$ of pure alcohol), but still was lower than maximum concentration proposed by national regulation $(1200 \mathrm{~g} / \mathrm{hL}$ of pure alcohol for fruit spirits and $1000 \mathrm{~g} / \mathrm{hL}$ of pure alcohol for grape spirit) except for one grape spirit sample (1162.2 g/hL of pure alcohol). Urea was detected in all analyzed samples (5.819 to $77.82 \mathrm{mg} / \mathrm{L}$ ) with the average concentration of $37.95 \mathrm{mg} / \mathrm{L}$. Since this is, to our knowledge, the first study that included the chemical analysis of homemade spirits in $\mathrm{BiH}$, these results are of great importance for the further research.
\end{abstract}

\section{INTRODUCTION}

Consumption of alcoholic beverages is a common habit of celebrations, with meals and even as a remedy in Bosnia and Herzegovina. For this reason, not only drinking but also homemade production of different kind of alcoholic beverages (wines and spirits) has a long tradition in all parts of Bosnia and Herzegovina. The most common kinds of spirits are those made of plums and grapes, but other different types of alcoholic beverages are also made (mostly of stone fruit). According to World Health Organization (WHO) homemade alcoholic beverages are considered as unregistered, which means that these products are not taxed as alcoholic beverages and also are not registered under a state provision (WHO, 2018). Globally, the most common category of unrecorded alcohol is homemade alcohol and regarding the type of alcohol, the biggest portion of unrecorded consumption can be attributed to spirits (Rehm, Larsen, Lewis-Laietmark, et al., 2016). In Bosnia and Herzegovina, general production, common analytical composition limits and parameters for the geographical denominations for strong distilled alcoholic beverages are defined by State Rulebook (2012). According to the results of a systematic analysis for the Global Burden of Disease for the period of 1990-2013 alcohol use is one of the ten leading risks in terms of attributable DALYs (disabilityadjusted life-years) not only globally, but also in Bosnia and Herzegovina (Forouzanfar, et al., 2015). Based on results of a systematic analysis for the Global Burden of Disease Study 2016 there is a growing trend of alcoholic beverages consumption in $\mathrm{B} \& \mathrm{H}$ over the last decades, especially among men $(5 \mathrm{~L}$ of alcohol per capita in 1990 vs. 6,5 L per capita in 2016) and it is estimated that $44 \%$ of total alcohol stock were not recorded (Griswold et al., 2018). The projection of the trend of alcohol consumption up to 2020 and 2025 in 
$\mathrm{B} \& \mathrm{H}$ shows a strong increase (up to $1.2 \mathrm{~L}$ ) compared to consumption in 2016 (WHO, 2018). Based on the WHO report on alcohol consumption in $\mathrm{B} \& \mathrm{H}$, spirits constitute $12 \%$ of all alcoholic beverages consumed in $\mathrm{B} \& \mathrm{H}$, and $28 \%$ of total consumed spirits have not been recorded. Data on proportion of unrecorded consumption in $\mathrm{B} \& \mathrm{H}$ vary depending on the sources used, but this can be explained by the fact that unrecorded consumption is derived mainly from the surveys by local experts based on fragmented data (WHO, 2018). A certain amount of compounds that are considered as contaminants, can be formed during production and present in alcoholic beverages, especially if distillation is conducted in uncontrolled home production. In addition to its potential health risk, unrecorded consumption can contribute to heavy drinking due to its low cost and availability (WHO, 2018). Most of the experts perceived unrecorded consumption as a financial, public health and social problem (Rehm, et al., 2016).

The main aim of this study was to investigate the presence of potentially toxic compounds (methanol, hydrocyanic acid, and urea) in homemade spirits produced in different parts of Bosnia and Herzegovina.

\section{EXPERIMENTAL}

A total of 15 samples of various homemade spirits from the different parts of Bosnia and Herzegovina were collected (Table 1.).

Table 1: Samples analyzed in this study

\begin{tabular}{|c|c|c|c|}
\hline Sample & Type of spirit & $\begin{array}{l}\text { Content of } \\
\text { ethanol }(\%)\end{array}$ & $\begin{array}{l}\text { Location of } \\
\text { production }\end{array}$ \\
\hline 1. & Apple spirit & 40 & $\begin{array}{c}\text { Mostar } \\
\text { (Herzegovina) }\end{array}$ \\
\hline 2. & Apricot spirit & 43 & Sarajevo (Bosnia) \\
\hline 3. & Apricot spirit & 40 & $\begin{array}{c}\text { Mostar } \\
\text { (Herzegovina) }\end{array}$ \\
\hline 4. & Cherry spirit & 40 & $\begin{array}{c}\text { Mostar } \\
\text { (Herzegovina) }\end{array}$ \\
\hline 5. & Grape spirit & 40 & $\begin{array}{c}\text { Čitluk } \\
\text { (Herzegovina) }\end{array}$ \\
\hline 6. & Grape spirit & 40 & $\begin{array}{c}\text { Čitluk } \\
\text { (Herzegovina) }\end{array}$ \\
\hline 7. & Juniper spirit & 40 & $\begin{array}{c}\text { Čitluk } \\
\text { (Herzegovina) }\end{array}$ \\
\hline 8. & Pear spirit & 40 & Sarajevo (Bosnia) \\
\hline 9. & Pear spirit & 38 & $\begin{array}{c}\text { Čapljina } \\
\text { (Herzegovina) }\end{array}$ \\
\hline 10. & Pear spirit & 38 & $\begin{array}{c}\text { Mostar } \\
\text { (Herzegovina) }\end{array}$ \\
\hline 11. & Plum spirit & 40 & Tuzla (Bosnia) \\
\hline 12. & Plum spirit & 40 & Tuzla (Bosnia) \\
\hline 13. & Plum spirit & 47 & Sarajevo (Bosnia) \\
\hline 14. & Plum spirit & 46 & $\begin{array}{c}\text { Čapljina } \\
\text { (Herzegovina) }\end{array}$ \\
\hline 15. & Quince spirit & 45 & Tuzla (Bosnia) \\
\hline
\end{tabular}

These spirits are usually made by distillation of the fermented fruit mash (apple, apricot, cherry, grape, pear, plum and quince). The juniper spirit is made by soaking the juniper berries in the plum spirit. The ethanol content of the samples analyzed is determined by measuring their density using an alcohol meter (Iberian Coppers S.A., Portugal).
All the reagents used in experimental work were of analytical grade and purchased from Sigma-Aldrich (St. Louis, MO, USA).

Distilled water was used for dilution and cleaning in all analytical procedures.

\section{Determination of methanol}

Methanol was determined using the spectrophotometric method after previous distillation (under atmospheric pressure). $1 \mathrm{~mL}$ of distillate was diluted in a volumetric flask $(25 \mathrm{~mL})$ with water. For the further analysis $1 \mathrm{~mL}$ of this solution was used.

Spectrophotometric method is based on oxidation of methanol to formaldehyde with potassium permanganate and further reaction with chromotropic acid. $2 \mathrm{~mL}$ of $3 \%$ potassium permanganate was added to $1 \mathrm{~mL}$ of previously diluted distillate and left for 30 minutes at room temperature, with occasional shaking. After 30 minutes, approximate $0.05 \mathrm{~g}$ of sodium bisulphite (p.a.) was added to reduce the excess of permanganate and also $1 \mathrm{~mL}$ of $5 \%$ aqueous chromotropic acid solution. After mixing, $15 \mathrm{~mL}$ of concentrated sulfuric acid was added and solution was heated in boiling water bath for 20 minutes.

Upon cooling to the room temperature, absorbance was measured at $575 \mathrm{~nm}$ against the reagent blank, and used for calculation of methanol content from the calibration curve previously prepared.

\section{Determination of cyanides}

Hydrocyanic acid in samples was determined using a silver nitrate titration with $p$-dimethylaminobenzylidene rhodanine indicator (EPA, 1996; APHA, 2005). This is the official method used in laboratory for food analysis in Federal Institute for Public Health in B\&H.

\section{Determination of urea}

Urea in samples was determined using spectrophotometric method previously published and originally proposed for the determination of urea in dermatological formulations and cosmetics (Bojic, Radovanovic, Dmitrijevic, 2008). In summary, $1 \mathrm{~mL}$ of native sample was transferred to volumetric flask and 1 $\mathrm{mL}$ of $2.33 \mathrm{M} \mathrm{HCl}$ and $1 \mathrm{~mL}$ of methyl orange solution $(0.6 \mathrm{mM})$ was added. The solution was diluted with approximately $2 \mathrm{~mL}$ of water and after addition of $1 \mathrm{~mL}$ of potassium bromate solution $(1 \mathrm{mM})$, diluted with water to volume $(10 \mathrm{~mL})$. Absorbance was measured at $505 \mathrm{~nm}$ after 20 minutes, and content of urea was calculated from the previously prepared calibration curve.

\section{RESULTS AND DISCUSSION}

Calibration curves were linear in range 100-1000 mg/L for methanol $\left(\mathrm{R}^{2}=0.999\right)$ and in range $10-100 \mathrm{mg} / \mathrm{L}$ for urea $\left(\mathrm{R}^{2}=0.994\right)$. 
The content of hydrocyanic acid and methanol in samples was calculated and expressed in $\mathrm{g} / \mathrm{hL}$ of pure alcohol $(\mathrm{g} / \mathrm{hL}$ pa). The content of urea was calculated and expressed in $\mathrm{mg} / \mathrm{L}$ of native sample (Table 2.).

The content of methanol ranged from 67.482 to 1162.2 $\mathrm{g} / \mathrm{hL} \mathrm{pa}$, with the average of $688.24 \mathrm{~g} / \mathrm{hL}$ pa.

The levels of hydrocyanic acid in analyzed samples ranged from ND to $17.1 \mathrm{~g} / \mathrm{hL}$ pa, with the average content of $8.96 \mathrm{~g} / \mathrm{hL}$ pa. In 3 out of 15 samples $(20 \%)$ HCN was not detected.

Urea was detected in all analyzed samples (5.819 to $77.82 \mathrm{mg} / \mathrm{L}$ ) with average concentration of $37.95 \mathrm{mg} / \mathrm{L}$.

Table 2: Summary of analytical results

\begin{tabular}{cccc}
\hline Sample & HCN $(\mathrm{g} / \mathrm{hL}$ pa) & Methanol $(\mathrm{g} / \mathrm{hL}$ pa $)$ & Urea $(\mathrm{mg} / \mathrm{L})$ \\
1. & 16.2 & 228.73 & 24.16 \\
2. & 5.01 & 955.51 & 63.62 \\
3. & 16.2 & 471.65 & 66.50 \\
4. & $\mathrm{ND}$ & 228.73 & 77.82 \\
5. & 10.8 & 67.482 & 5.819 \\
6. & 5.40 & 1162.2 & 7.340 \\
7. & $\mathrm{ND}$ & 561.82 & 75.20 \\
8. & 5.40 & 848.38 & 48.88 \\
9. & 17.1 & 545.84 & 32.57 \\
10. & 5.68 & 1099.9 & 60.33 \\
11. & 10.8 & 1024.3 & 19.21 \\
12. & 5.40 & 806.87 & 18.12 \\
13. & ND & 1098.7 & 32.48 \\
14. & 4.69 & 709.57 & 24.12 \\
15. & 4.80 & 513.97 & 13.04 \\
mean & $\mathbf{8 . 9 6}$ & $\mathbf{6 8 8 . 2 4}$ & $\mathbf{3 7 . 9 5}$ \\
STD & $\mathbf{5 . 0 3}$ & $\mathbf{3 4 9 . 3 2}$ & $\mathbf{2 5 . 1 4}$ \\
\hline
\end{tabular}

Legend: 1- apple; 2,3-apricot; 4-cherry; 5,6-grape;7-juniper; 810 pear; 11-14 plum; 15-quince; ND-not detected

When grouping the samples based on the region of their origin and production, no significant difference was observed among mean values for the different toxic components (Table 3.).

Table 3: Levels of investigated toxic components in analyzed samples grouped based on the region of production

\begin{tabular}{cccc}
\hline \multicolumn{2}{c}{ Region } & Bosnia & Herzegovina \\
\hline Number of samples & 6 & 9 \\
\hline HCN & range & ND-10.8 & ND-17.1 \\
\cline { 2 - 4 }$(\mathrm{g} / \mathrm{hL} \mathrm{pa})$ & mean \pm STD & $5.24 \pm 3.43$ & $8.45 \pm 6.84$ \\
\hline Methanol & range & $514.97-1098.7$ & $67.482-1162.2$ \\
\cline { 2 - 4 }$(\mathrm{g} / \mathrm{hL} \mathrm{pa})$ & mean \pm STD & $874.62 \pm 207.13$ & $563.99 \pm 378.55$ \\
\hline Urea & range & $13.04-63.62$ & $5.819-77.82$ \\
\cline { 2 - 4 }$(\mathrm{mg} / \mathrm{L})$ & mean \pm STD & $32.56 \pm 19.99$ & $41.54 \pm 28.63$ \\
\hline
\end{tabular}

In general, the average content of methanol was higher in samples from Bosnia comparing to the samples from Herzegovina (874.62 g/hL pa vs. $563.99 \mathrm{~g} / \mathrm{hL}$ pa), but still was lower than maximum concentration proposed by national Rulebook on strong alcoholic beverages (2012) (1200 g/hL pa for fruit spirits and $1000 \mathrm{~g} / \mathrm{hL}$ pa for grape spirit) except for one grape spirit sample (1162.2 g/hL pa).

Other reports on average content of methanol in samples of apple, cherry, plum and pear spirits were similar to those found in our study (Bauer-Christoph, Watchter, Christoph, et al., 1997; Winterová, Mikulíková, Mazáč, et al., 2008). Content of methanol recorded in two samples of grape spirit was 67.482 and $1162.2 \mathrm{~g} / \mathrm{hL}$ pa. This variation in results is probably due to different grape processing and the distillation techniques, as well as to the different grape variety used for production of spirits analyzed. These findings are similar to those previously published (Geroyiannaki, Komaitis, Stavrakas, et al., 2007). Average content of methanol in samples from Bosnia (874.62 $\mathrm{g} / \mathrm{hL}$ pa) was higher than methanol content previously reported for spirits from Hungary (20-616 g/hL pa), Lithuania (ND-29 g/hL pa) (Lachenmeier, Sarsh, Rehm, 2009a), Ukraine (ND-262 $\mathrm{g} / \mathrm{hL}$ pa) (Lachenmeier, Samokhvalov, Leitz, et al., 2010) and Poland (ND-757 g/hL pa) (Lachenmeier, Ganss, Rychlak, et al., 2009b). The highest content of methanol was found in plum spirits (mean value 909.86 $\mathrm{g} / \mathrm{hL} \mathrm{pa),} \mathrm{which} \mathrm{is} \mathrm{in} \mathrm{line} \mathrm{with} \mathrm{previously} \mathrm{published}$ results for the methanol content in plum spirits originated from this region (Filajdic and Djukovic, 1973).The average content of HCN ( $8.45 \mathrm{~g} / \mathrm{hL}$ pa) in spirits from Herzegovina was higher than maximum permissible level (MPL) proposed by aforementioned regulation $(7 \mathrm{~g} / \mathrm{hL} \mathrm{pa})$ and in 4 out of 9 samples (apple, apricot, grape and pear) content was almost two times higher than MPL. Only one sample from Bosnia (plum spirit) had content of HCN higher than MPL (10.8 g/hL pa). The average content of $\mathrm{HCN}$ in plum spirits was $5.22 \mathrm{~g} / \mathrm{hL}$ pa, which is bit higher than previously published data for plum brandies from Poland and Slovakia (0.1 and $0.6 \mathrm{~g} / \mathrm{hL}$ pa, respectively). According to Satora and Tuszynski (2008) these differences can be due to the different technologies of production.

The average content of urea in all analyzed samples was $37.95 \mathrm{mg} / \mathrm{L}$, with highest content in cherry spirit $(77.82$ $\mathrm{mg} / \mathrm{L})$ and juniper spirit $(75.20 \mathrm{mg} / \mathrm{L})$. The lowest content was recorded for two grape spirits from Herzegovina (5.819 and $7.340 \mathrm{mg} / \mathrm{L}$ ). These findings are similar to those reported by Polastro, Boso and AndradeSobrinho (2001) for distilled beverages from different parts of Brazil. Labanca and Gloria (2008) investigated 68 samples of sugar cane spirits from Brazil and in only $4 \%$ of the samples urea content was higher than $3 \mathrm{mg} / \mathrm{L}$. Urea is considered as one of the precursors to the formation of ethyl carbamate in fermented and distilled beverages. Ethyl carbamate can be also formed from the reaction of other precursors such as cyanide and ethanol (Jiao, Dong, Chen, 2014; Gowda, Sua, Karlovsky, et al., 2018). According to Ayloit, Cochrane and Leonard (1990) monitoring of initial concentrations of ethyl carbamate precursors in freshly distilled spirits can be useful guide for predicting final ethyl carbamate concentration in mature spirit. The CONTAM Panel for a scientific opinion on the risks to human health related to the presence of ethyl carbamate and hydrocyanic acid in food and alcoholic beverages concluded that ethyl carbamate in alcoholic beverages indicates a health concern, particularly with respect to stone fruit brandies (EFSA, 2007). According to EFSA (2007), mitigation measures should be taken to reduce the levels of ethyl carbamate in certain alcoholic beverages such as fruit brandies, and such measures should focus on hydrocyanic acid and other precursors of ethyl carbamate to prevent the formation of ethyl carbamate 
during shelf-life of these products. Despite the small number of samples, these are the first data on the toxic components of locally produced spirits. Considering that the consumption of these spirits is quite common in $\mathrm{B} \& \mathrm{H}$, our findings are of great interest to the local community.

\section{CONCLUSIONS}

The toxic components that we have analyzed in our fruit spirit samples can pose a health hazard to consumers, especially if they are present in high concentrations. In one third of our samples, content of hydrocyanic acid was higher than MPL. The urea content of all the samples was relatively high, which can be of importance bearing in mind that urea is one of the most important precursors of ethyl carbamate. Since this is, to our knowledge, the first study that included a chemical analysis of homemade spirits in $\mathrm{B} \& \mathrm{H}$, these results are of great importance for the further research that clearly needs to be undertaken.

\section{REFERENCES}

American Public Health Association (APHA). (2005). Standard Methods for the Examination of Water and Wastewater.21. Washington, DC. Method 4500-CN

Ayloit, R. I., Cochrane, G. C., Leonard, M. J., Macdonald, L. S., Mackenzie, W. M., Mcneish, S., Walker, D. A. (1990). Ethyl carbamate formation in grain based spirits part I: postdistillation ethyl carbamate formation in maturing grain whisky. J lnst Brew, 96, 213-221.

Bauer-Christoph, C., Wachter, H., Christoph, N., Roßmann, A., Adam, L. (1997). Assignment of raw material and authentication of spirits by gas chromatography, hydrogen- and carbon-isotope ratio measurements I. Analytical methods and results of a study of commercial products. $Z$ Lebensm Unters Forsch, 204, 445-452.

Bojic, J., Radovanovic, B., Dimitrijevic, J. (2008). Spectrophotometric Determination of Urea in Dermatologic Formulations and Cosmetics. Analytical Sciences, 24, 769-774.

EFSA. (2007). EFSA Opinion of the Scientific Panel on Contaminants in the Food chain on a request from the European Commission on ethyl carbamate and hydrocyanic acid in food and beverages. The EFSA Journal, 551, 1-44.

Filajdic, M., Djukovic, J. (1973). Gas-Chromatographic Determination of Volatile Constituents in Yugoslav Plum Brandies. J Sci Food Agric, 24, 835-842.

Forouzanfar, M. H., GBD 2013 Risk Factors Collaborators. (2015). Global, regional, and national comparative risk assessment of 79 behavioural, environmental and occupational, and metabolic risks or clusters of risks in 188 countries, 1990-2013: a systematic analysis for the Global Burden of Disease Study 2013. Lancet, 386, 2287-323.
Geroyiannaki, M., Komaitis, M. E., Stavrakas, D. E., Polysiou, M., Athanasopoulos, P. E., Spanos, M. (2007). Evaluation of acetaldehyde and methanol in greek traditional alcoholic beverages from varietal fermented grape pomaces (Vitis vinifera L.). Food Control, 18, 988-995.

Gowda, V., Sua, H., Karlovsky, P., Chena, W. (2018). Ethyl carbamate: An emerging food and environmental toxicant. Food Chemistry, 248, 312-321.

Griswold M. G. GBD 2016 Alcohol Collaborators. (2018). Alcohol use and burden for 195 countries and territories, 1990-2016: a systematic analysis for the Global Burden of Disease Study 2016. Lancet, 392(10152), 1015-1035.

Jiao, Z., Dong, Y., Chen, Q. (2014). Ethyl Carbamate in Fermented Beverages: Presence, Analytical Chemistry, Formation Mechanism, and Mitigation Proposals. Comprehensive Reviews in Food Science and Food Safety, 13, 611-626.

Labanca, R. A., Gloria, B. A. (2008). Spectrophotometric Determination of Urea in Sugar Cane Distilled Spirits. J Agric Food Chem, 56, 5211-5215.

Lachenmeier, D. W., Ganss, S., Rychlak, B., Rehm, J., Sulkowska, U., Skiba, M., Zatonski, W. (2009b). Association between Quality of Cheap and Unrecorded Alcohol Products and Public Health Consequences in Poland. Alcohol Clin Exp Res, 33 (10), 1757-1769.

Lachenmeier, D. W., Samokhvalov, A. V., Leitz, J., Schoeberl, K., Kuballa, T., Linskiy, I. V., Minko, O. I., Rehm J. (2010). The composition of unrecorded alcohol from eastern Ukraine: Is there a toxicological concern beyond ethanol alone? Food and Chemical Toxicology, 48, 2842-2847.

Lachenmeier, D. W., Sarsh, B., Rehm, J. (2009a). The Composition of Alcohol Products from Markets in Lithuania and Hungary, and Potential Health Consequences: A Pilot Study. Alcohol and Alcoholism, 44 (1), 93-102.

Polastro, L. R., Boso, L. M., Andrade-Sobrinho, L. G., Lima-Neto, B. S., Franco, D. (2001). Nitrogen compounds in distilled beverages: sugar cane and cassava spirits. Ciência e Tecnologia de Alimentos, 21 (1), 78-81.

Pravilnik o definiranju, opisivanju, prezentiranju, označavanju i zaštiti geografskih oznaka jakih alkoholnih pića. (2012). Službeni glasnik BiH 81. Available

http://www.fsa.gov.ba/fsa/images/pravnipropisi/bs-

Pravilnik_o_definiranju_opisivanju_prezentiranju _ozna\%C4\%8Davanju_i_za\%C5\%A1titi_geograf skih_oznaka_jakih_alkoholnih_pi\%C4\%87a_8112.pdf (04/04/2019)

Rehm, J., Larsen, E., Lewis-Laietmark, C., Gheorghe, P., Poznyak, V., Rekve, D., Fleischmann, A. (2016). Estimation of Unrecorded Alcohol Consumption in Low-, Middle-, and High-Income Economies for 2010. Alcohol Clin Exp Res, 40 (6), 12831289. 
Satora, P., Tuszynski, T. (2008). Chemical characteristics of Sliwowica Lacka and other plum brandies. J Sci Food Agric, 88, 167-174.

United States Environmental Protection Agency (EPA). (1996). Titrimetric and manual spectrophotometric determinative methods for cyanide. Method 9014
Winterová, R., Mikulíková, R., Mazáč, J., Havelec, P. (2008). Assessment of the authenticity of fruit spirits by gas chromatography and stable isotope ratio analyses. Czech J Food Sci, 26, 368-375.

World Health Organization. (2018). Global status report on alcohol and health. Geneva, Switzerland. Licence: CC BY-NC-SA 3.0 IGO.

\section{Summary/Sažetak}

Glavni cilj ovog preliminarnog istraživanja bio je da se ispita prisustvo potencijalno toksičnih sastojaka (metanol, cijanidna kiselina i urea) u domaćim rakijama proizvedenim u različitim dijelovima Bosne i Hercegovine. Ukupno je analizirano 15 uzoraka voćnih rakija napravljenih od 8 vrsta voća (jabuka, kajsija, višnja, grožđe, šljiva, kruška, dunja i kleka). U pet od 15 ispitivanih uzoraka sadržaj cijanidne kiseline bio je iznad maksimalno dozvoljene koncentracije. Uopšteno, prosječni sadržaj metanola bio je viši u uzorcima sa lokaliteta u Bosni u odnosu na uzorke proizvedene u Hercegovini (874.62 prema $563.99 \mathrm{~g} / \mathrm{hl}$ čistog alkohola), ali i dalje je bio ispod maksimalno dozvoljene koncentracije predložene državnom regulativom (1200 g/hl čistog alkohola za voćne rakije i $1000 \mathrm{~g} / \mathrm{hl}$ čistog alkohola za lozovaču) osim za jedan uzorak lozovače $(1162.2 \mathrm{~g} / \mathrm{hl}$ čistog alkohola). Urea je detektovana u svim ispitivanim uzorcima $(5.819 \mathrm{do} 77.82 \mathrm{mg} / \mathrm{l}) \mathrm{sa}$ prosječnim sadržajem od $37.95 \mathrm{mg} / \mathrm{l}$. S obzirom da su ovo, po našem saznanju, prvi podaci o hemijskoj analizi domaćih rakija u $\mathrm{BiH}$, od velikog su značaja za dalja obimnija istraživanja, koja je svakako potrebno provesti. 